\title{
Roles of Selected Psycho-Demographic Factors on Quality of Sex Life and Marital Satisfaction among Dual-career Couples
}

\author{
Matthew O. Olasupo ${ }^{1 *}$ \\ ${ }^{I}$ Department of Psychology, Obafemi Awolowo University, Ile-Ife, Nigeria
}

Received 19.03.2020; Received revised 9.06.2020; Accepted 15.06.2020; Available online 30.06 .2020

\begin{abstract}
The study investigated the predictive roles of career self-efficacy, work-life balance and selected demographic factors on the quality of sex life and marital satisfaction among dual-career couples in Obafemi Awolowo University Ile-Ife, and assessed if there are significant differences between men and women. The study used a cross-sectional research design and 1056 dual-career men and women $($ age $=43.98, \sigma=9.48, ~ \&=37.0 \%)$ participated in the study. A self-administered paper and pencil questionnaire was used to collect data from samples that were conveniently drawn from the study area. Data were analyzed using Structural Equation Modelling (SEM). Results showed significant differences in structural weights, structural covariances, and structural residuals in the model outputs for both men and women careerists. The study concluded that career self-efficacy and work-life balance differentially predict the quality of sex life and marital satisfaction for both men and women in a dual-career family, and that age and job tenure are not significant predictors of quality of sex life and marital satisfaction among dual-career couples.
\end{abstract}

Keywords: Age, job tenure, career self-efficacy, quality of sex life, marital satisfaction, work-life balance, dual-career couples.

Address of correspondence: Matthew O. Olasupo, Department of Psychology, Obafemi Awolowo University, 220005 Ife, Nigeria E-mail: gbenga.olasupo@oauife.edu.ng.

Changes in the social and economic situation in Nigeria and at large globally are leading into an upsurge of more families adopting dual-career options (Lirio, 2017; Ugwu, 2009). This has challenged the age-long cultural norms of gender-specific roles in the Nigerian family (Balogun, 2010). The traditional gender role regards the man as the 'breadwinner' and the woman, 'home-maker' (Abidogun, 2007; Agbalajobi, 2010; Cornwall, 2002; Jacobs \& Gerson, 2001). Meanwhile, with about $68 \%$ Nigerians living below the income poverty line and about $33.9 \%$ living in severe poverty (UNDP, 2013), it is becoming more expedient for the wives who ordinarily by local tradition should be home-makers to engage in employment to augment the family income. The challenge for the couple then is on how to successfully fulfil the family demands and meet career expectations (Arthur \& Parker, 2004). This fuss has brought stress and conflict upon many dual-earner families (Fischlmayr \& Puchmüller, 2016; Lirio, 2017; Shambaugh, 2017).

The resiliency model of family stress, adjustment and adaptation was proposed by McCubbin and McCubbin (1983) based on Hill's (1949) theory of family stress. This model explains that all family experiences crises and stressful situations, albeit differentially and that outcomes depend on each family's adaptation rather than adjustment. The model identifies the factors that influence the outcome of a stressful situation as family resources (including family members' resources like personality traits, intelligence, self-esteem, self-efficacy, locus of control, attribution), social support, family types, and situational appraisal. The availability and the utilization of these resources are what determines the successful and unsuccessful family functioning during crises adjustment (Robinson, 1991)

The term 'dual-career family' was defined by Rapoport and Rapoport $(1969,1976)$ to mean a type of family structure in which both heads of household - the husband and the wife - pursue an active career and family lives. Hall and Hall (1978) elaborated the term to describe a couple either married or living together who are both employed. The idea of both husband and wife in a paid workforce is not without its benefit, both to the individuals that are involved. Arthur and Parker (2004) describe a career as an avenue for self-fulfilment and personal development as this allows more women to fulfil themselves in the world of work. It is also reported that 
many traditional housewives do complain of lack of inner fulfilment and personal development when they are prevented from participating in the active workforce (Haddock \& Rattenborg, 2003).

Another benefit of the dual-career family is an economic gain. Where the housewife engages in paid employment, it enhances the family purse and brings economic relief to the husband (Haddock \& Rattenborg, 2003). Furthermore, sufficient economic resources enable the family to enhance the quality of their children's physical environment, have access to better medical care, and better educational opportunities and resources. Dualcareer family is believed to enhance egalitarianism in the home as it promotes gender equality between husband and wife, promotes the utilization of professional skills and elevates a possible closer relationship between father and the child, advances intellectual companionship between marital partners, and upgrades increased understanding of what marital partner experiences daily (Lupo et al., 2015)

One of the most difficult challenges facing the dualcareer family is trying to balance the demands of occupation with the expectations of the family (Watanabe et al., 2017). This problem is even compounded when both husband and wife work in different geographical locations (McFall \& Murray-Close, 2016). This creates the argument of whose career takes priority, who is to be in the custody of the children, the issue of infidelity, who does what in maintaining the household chores, who runs the errands among others (Motte-Baumvol, Bonin, \& BeltonChevallier, 2015; Shambaugh, 2017). The problem may even get more complicated where there are other dependents like aged parents, in addition to the children. This undoubtedly increases role overload on both sides. Higgins and Duxbury (1992); Ugwu (2009) reported that more dual-career couples reported more role overload than their traditional career counterparts and those who receive assistance from house-helps. Also, Schlessinger (2000) noted that children of dual-career couples enjoy less time, attention, and commitment from their parents. The ability to successfully deploy coping resources like self-efficacy and work-life balance may have roles to play in successfully coping with the emerging crises. Additionally differences in experiences like age and job tenure may be predicting factors.

Studies have been examining the measures being put in place at the organizational and family levels to assist dualearner couples to cope effectively with work-family demands (Fischlmayr \& Puchmüller, 2016; Lirio, 2017; Schooreel \& Verbruggen, 2016). Organizational measures include the adoption of technological advancement to create a home office, virtual office, and the adoption of flexi workers and shift jobs. Most organizations now allow day-care facilities/crèche within organizational premises. Families also incorporate the assistance of house-helps, just as more husbands now get involved in domestic chores. All these are aimed to enhance the work-life balance of dual-career couples. Where there is scant in the literature is that researchers have not examined how psychological variables like work-life balance, career selfefficacy (conviction in one's own ability to perform on a given job task), and some demographic variables such age and job tenure affect the quality of sex life and marital satisfaction of dual-career couples which is the aim of this study. Therefore, the study hypothesized that there is a significant predictive influence of career self-efficacy, work-life balance, age and job tenure on the quality of sex life and marital satisfaction among dual-earner families and that the influence will differ significantly for female and male careerists.

\section{Method}

\section{Study Participants}

The study employed a cross-sectional survey method. One thousand, six hundred and eighty-four (1684) employees of Obafemi Awolowo University Ile-Ife, Nigeria participated in the study. These were conveniently selected across all the faculties and departments in the university, including both academic and supporting staff members. In the course of data screening, all employees who were not married and widowed were dropped out of the analysis. Also, those whose spouses were not into fulltime employment were excluded. This we did to ensure that only data from dual-career employees were analyzed. We were then left out with 1056 respondents in the final analysis. Their age ranges from 23 to 61 with mean ages of 41. Among the respondents were 102 males and 86 females. Selection cuts across all the thirteen faculties of the University including both the academic and administrative staff members.

\section{Measure}

A single paper and pencil questionnaire with five (5) sections was used to collect data from the study participants. Section A of the questionnaire sought information on respondents' demographics such as age, gender, years of service, years of marriage, religious affiliation, and category of staff (academic, administrative, or technical).

Section B of the scale measures career self-efficacy using the New General Self-efficacy (NGSE) scale developed by Chen, Gully, and Eden (2001). The NGSE is an 8 -item, Likert-type $(1=$ strongly disagree, $5=$ strongly agree) that measures an individual's capabilities to mobilize resources and courses of action needed to meet given situational demands. Sample items include "When facing difficult tasks, I am certain that I will accomplish them", "I am confident that I can perform effectively on many different tasks", "Even when things are tough, I can perform quite well". Chen et al. (2001) reported Cronbach Alpha of .85 for the internal consistency and test-retest stability coefficient of .86 with high content and predictive validity. We found a Cronbach Alpha of .88 in this study which makes the scales suitable for use in our setting.

Section $\mathrm{C}$ of the questionnaire measures Work-Life balance using the Industrial Society's Work-Life Checklist (Checklist 10) (Dex \& Bond, 2005). It is a 10-item, Likerttype $(1=$ agree, $3=$ disagree $)$. Sample items include "At the moment because the job demands it, I usually work long hours", "There isn't much time to socialize/relax with my partner/see family in the week", "My relationship with my partner is suffering because of the pressure or long hours of my work". Authors reported a Cronbach Alpha of .80 for the reliability of internal consistency with high content and predictive validity. In this study, we found a Cronbach Alpha of .86 which makes it suitable for our use.

Section C measures the quality of sex life using the quality of sexual life questionnaire (QoSL-Q) developed by Moore et al. (2002). It is a 5-item, Likert-type scale that assesses the quality of sex life. Sample items include "How often did you discuss sex with your partner?", "Are you being satisfied with your sexual life with your partner?", "Do you ever reject sexual overtures from your partner?". Authors reported a Cronbach Alpha of .74 to 
confirm the reliability of the scale. It is also reported that QoSL -Q shows high predictive quality. In this study, we found a Cronbach alpha of .76 providing support for its suitability for use.

Marital satisfaction was measured in section D using the Kansas Marital Satisfaction Scale (KMS). It is 3-item, Likert-type ( 1 = extremely dissatisfied, 7 = extremely satisfied) scale developed by Schumm et al. (1986) to measure marital satisfaction. Items on the scale are "How satisfied are you with your marriage?", "How satisfied are you with your husband/wife as a spouse?", and "How satisfied are you with your relationship with your husband/wife?". Authors reported an excellent internal consistency for the scale with a Cronbach Alpha of .93 and an excellent concurrent validity. We established a Cronbach Alpha of .84 in this study.

\section{Procedure}

We sought and got ethical approval from the Research and Ethical Committee of the Department of Psychology, Obafemi Awolowo University Ile-Ife. With the help of postgraduate students, questionnaires were given to all the employees of Obafemi Awolowo University Ile-Ife. Copies were sent to all the offices. One week was given to fill and complete the questionnaires. Students went back after one week to retrieve the questionnaires. We were able to retrieve 1684 of the administered questionnaires. We then excluded all employees who were single, widows and widowers, and those whose spouses were not engaged in full-time employment. After screening and cleaning, 1056 of this questionnaires were eventually analyzed.

\section{Data analysis}

Data were analyzed using structural equation modelling performed by IBM SPSS Amos 23.

\section{Results}

\section{Respondents' Socio-demographics}

The socio-demographics of the study participants are presented in Table I. It could be observed that there were more male participants $(63 \%)$ than were female participants $(37 \%)$. The majority of the participants are also of Christian extraction (78.4\%). Only $20.8 \%$ of the participants were Muslims and $.8 \%$ practices traditional faith. Academic staff members were $57.6 \%$, Administrative staff was $33.3 \%$ while Technical staff was $9.1 \%$. We were not amazed that the majority of respondents $(58 \%)$ had postgraduate educational qualifications as the respondents were university employees. We were however astonished to note that there were respondents with primary education $(.3 \%)$ who are mostly cleaners and gardeners.

\section{Preliminary analyses}

Prior to the main analyses, data were scanned for any missing values. All respondents who fail to answer up to $20 \%$ of total questions were removed from the study. Meanwhile, those whose missing data is not up to $5 \%$ were treated using mean substitution approach. Furthermore, data were also screen for univariate normality assumption where skewness and kurtosis of the distribution were examined.

The result of the univariate normality test shows that all the skewness and kurtosis of the survey items are all below the threshold set by Kline (2015). Multivariate outliers were screened using Mahalanobis distance and no potential outlier was discovered.

Table 1. Respondents' socio-demographics $(\mathrm{N}=1056)$

\begin{tabular}{|c|c|c|c|}
\hline Characteristics & Frequency & $\%$ & Mean (SD) \\
\hline Age & & & $43.98(9.48)$ \\
\hline \multicolumn{4}{|l|}{ Gender } \\
\hline Male & 665 & $63.0 \%$ & \\
\hline Female & 391 & $37.0 \%$ & \\
\hline \multicolumn{4}{|l|}{ Education } \\
\hline Primary & 03 & $0.3 \%$ & \\
\hline Secondary & 143 & $13.5 \%$ & \\
\hline Graduate & 297 & $28.1 \%$ & \\
\hline Postgraduate & 613 & $58.0 \%$ & \\
\hline \multicolumn{4}{|l|}{ Religion } \\
\hline Christianity & 828 & $78.4 \%$ & \\
\hline Islam & 220 & $20.8 \%$ & \\
\hline Traditional Religion & 08 & $0.8 \%$ & \\
\hline \multicolumn{4}{|l|}{ Staff Category } \\
\hline Academic & 608 & $57.6 \%$ & \\
\hline Administrative & 352 & $33.3 \%$ & \\
\hline Technical & 96 & $9.1 \%$ & \\
\hline
\end{tabular}

\section{Primary analyses}

Structural equation modelling with maximum likelihood approach was used in this study with the assessment of both measurement and structural model. The measurement model aims to validate whether the factor structure of the variables in the hypothesized model is supported by the sample data. In other to carry out the confirmatory factor analysis (CFA), pooled confirmatory factor analysis was carried out where all items (indicators) were linked to their respective latent variables. The result of the model shows that model fit indices are good $\chi 2(113, \mathrm{~N}=1056)=$ $385.53, \mathrm{p}=.001, \mathrm{CMIN} / \mathrm{DF}=3.412, \mathrm{CFI}=.965, \mathrm{TLI}=.957$; RMSEA $=.048(.43-.053), \quad$ PCLOSE $=.747)$. We also evaluated the construct, convergent and discriminant validity of the measurement model, and found that the construct reliability coefficient of all the variables under investigation met the recommended value (.6) of Hair, Anderson, Babin, and Black (2010). The result shows that all the items in each of the latent construct are a reliable measure of those constructs.

After controlling for common method bias using confirmatory factor analysis CLF approach, we ran the structural model (Figure I\&II). The fit indices of the structural equation model are very good $\chi 2(1, \mathrm{~N}=1056)=$ $1.57, \mathrm{p}=.21, \mathrm{CMIN} / \mathrm{DF}=1.566, \mathrm{CFI}=.999, \mathrm{RMSEA}=.023$, PCLOSE=.647). All the model fit measures satisfy the standard recommendation ( $\mathrm{Hu} \&$ Bentler, 1999). The adjusted model output for men and women are as shown in figure I and II below.

We noticed that there are differences in structural weights, structural covariances and structural residuals in the model outputs for both men and women. For men (Figure I), we observed that career self-efficacy is a significant predictor of quality of sex life $(\beta=.19, \mathrm{p}<.01)$ and not a significant predictor of marital satisfaction $(\beta=$ $.00, p=.99)$ but has an indirect but significant effect on marital satisfaction through quality of sex life $(\beta=.11$, $\mathrm{p}<.01)$. Work-life balance is also a significant predictor of quality of sex life for men $(\beta=.45, \mathrm{p}<.01)$ and not a significant predictor of marital satisfaction $(\beta=.03, p=$ .39). Age and job tenure are not significant predictors of quality of sex life $(\beta=-.05, \mathrm{p}=.39 ; \beta=-.05, \mathrm{p}=.36)$ and marital satisfaction $(\beta=-.05, \mathrm{p}=.34 ; \beta=.04, \mathrm{p}=.50)$. 
Quality of sex life is strongest predictor of marital satisfaction $(\beta=.44, \mathrm{p}<.01)$ for men (Table II).

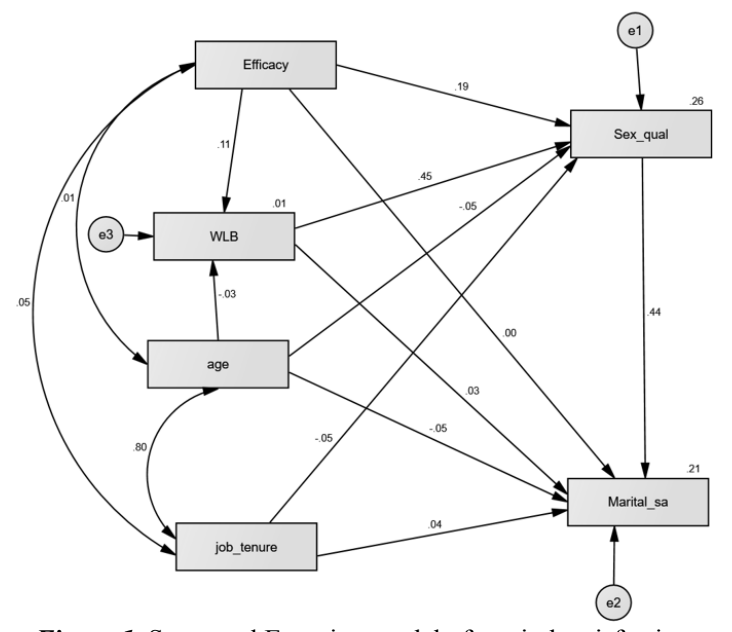

Figure 1. Structural Equation model of marital satisfaction and Sex quality (Men)

For women, career self-efficacy is a stronger and significant predictor of quality of sex life than for men $(\beta=$ $.29, \mathrm{p}<.01)$ and not a significant predictor of marital satisfaction for women as well $(\beta=.06, p=.14)$ but like men have an indirect and significant effect on marital satisfaction through quality of sex life $(\beta=.11, \mathrm{p}<.01)$.
Furthermore, work-life balance is also a stronger and significant predictor of quality of sex life for women than men $(\beta=.33, p<.01)$ but not a significant predictor of marital satisfaction for women as well $(\beta=.01, \mathrm{p}=.89)$.

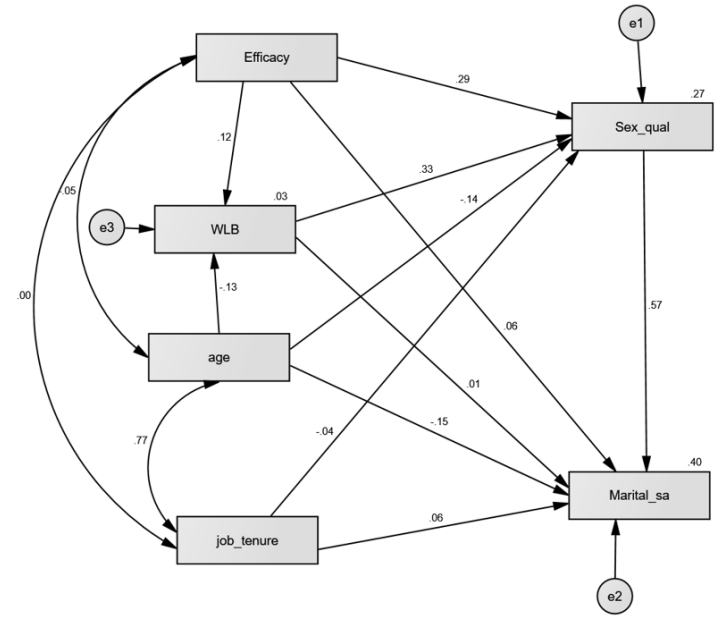

Figure 2. Structural Equation model of marital satisfaction and Sex quality (Women)

Table 2. Summary of Causal Effects for the Revised Model

\begin{tabular}{|c|c|c|c|c|c|c|c|}
\hline \multirow[b]{3}{*}{ Outcome } & \multirow[b]{3}{*}{ Predictors } & \multicolumn{3}{|c|}{ Men } & \multicolumn{3}{|c|}{ Women } \\
\hline & & \multicolumn{3}{|c|}{ Causal Effects } & \multicolumn{3}{|c|}{ Causal Effects } \\
\hline & & Direct & Indirect & Total & Direct & Indirect & Total \\
\hline Work-life balance & Career self-efficacy & $.11^{* *}$ & - & .11 & $.12 *$ & - & .12 \\
\hline $\begin{array}{l}\text { Men }\left(\mathrm{R}^{2}=.02\right) \\
\text { Women }\left(\mathrm{R}^{2}=.02\right)\end{array}$ & Age & $-.03 *$ & - & -.03 & $-.13 *$ & - & .13 \\
\hline Marital Satisfaction & Career self-efficacy & .00 & $.11 * *$ & .11 & .06 & $.11^{* *}$ & .11 \\
\hline $\operatorname{Men}\left(\mathrm{R}^{2}=.21\right)$ & Work-life balance & .03 & $.52 * *$ & .55 & .01 & $.52 * *$ & .53 \\
\hline \multirow[t]{3}{*}{ Women $\left(\mathrm{R}^{2}=.41\right)$} & Age & -.05 & -.00 & -.05 & $-.15^{*}$ & -.00 & -.15 \\
\hline & Job tenure & -.04 & -.00 & -.04 & .06 & $-.00 *$ & -.06 \\
\hline & Quality of sex life & $.44 * *$ & - & .44 & $.57 * *$ & - & .57 \\
\hline Quality of sex life & Career self-efficacy & $.19^{* *}$ & $.03 * *$ & .21 & $.29 * *$ & $.03 * *$ & .32 \\
\hline $\operatorname{Men}\left(\mathrm{R}^{2}=.26\right)$ & Work-life balance & $.05 * *$ & - & .05 & $.33 * *$ & - & .33 \\
\hline \multirow[t]{2}{*}{ Women $\left(\mathrm{R}^{2}=.28\right)$} & Age & -.05 & -.00 & -.05 & -.14 & -.00 & .14 \\
\hline & Job tenure & -.05 & - & -.05 & -.04 & - & -.04 \\
\hline
\end{tabular}

Contrary to what obtains for men, age has a negative and significant effect on the quality of sex life $(\beta=-.14$, $\mathrm{p}<.05)$ and marital satisfaction $(\beta=-.15, \mathrm{p}<.05)$ for women. Meanwhile as obtained for the men, job tenure is not a significant predictor of quality of sex life $(\beta=-.04, p$ $=.56)$ and marital satisfaction $(\beta=.06, p=.37)$ for the women as well. Quality of sex life also serves as the strongest predictor of marital satisfaction for the women (Table II).

We also sought to examine if the fitted models are different for men and women. The CMIN in Table III shows the likelihood ratio chi-square statistic for the fitted models. For structural weights (path coefficients) and residuals (variances), it can be observed that the data did depart significantly for men and women $(p<.05)$ indicating that there is a difference between men and women as far as the model is concerned. Meanwhile, there is no significant difference between men and women in structural covariances $(\mathrm{p}=.11)$.

Table 3. Nested Model Comparison of Men and Women

\begin{tabular}{lcccrrrr}
\hline Model & DF & CMIN & P & $\begin{array}{r}\text { NFI } \\
\text { Delta- } \\
1\end{array}$ & $\begin{array}{r}\text { IFI } \\
\text { Delta- } \\
2\end{array}$ & $\begin{array}{r}\text { RFI } \\
\text { rho- } \\
1\end{array}$ & $\begin{array}{r}\text { TLI } \\
\text { rho2 }\end{array}$ \\
\hline $\begin{array}{l}\text { Structural } \\
\text { weights }\end{array}$ & 11 & 21.045 & .033 & .012 & .012 & .023 & .023 \\
$\begin{array}{l}\text { Structural } \\
\text { covariances }\end{array}$ & 17 & 24.443 & .108 & .014 & .014 & .017 & .017 \\
$\begin{array}{l}\text { Structural } \\
\text { residuals }\end{array}$ & 20 & 40.085 & .005 & .023 & .023 & .026 & .026 \\
\hline
\end{tabular}


Table 4. Critical Ratio for Differences between Men and Women

\begin{tabular}{|c|c|c|c|c|c|c|c|}
\hline \multicolumn{3}{|c|}{$\underline{\text { Variables }}$} & \multicolumn{2}{|l|}{$\underline{M e n}$} & \multicolumn{3}{|l|}{ Women } \\
\hline Dependent & & Predictors & Estimate & $P$ & Estimate & $P$ & $z$-score \\
\hline Work-life balance & $<---$ & Career self-efficacy & 0.072 & 0.006 & 0.079 & 0.016 & 0.167 \\
\hline Work-life balance & $<---$ & age & -0.001 & 0.422 & -0.006 & 0.011 & -1.583 \\
\hline Quality of sex life & $<---$ & Career self-efficacy & 0.103 & 0.000 & 0.180 & 0.000 & $2.355^{* *}$ \\
\hline Quality of sex life & $<---$ & Work-life balance & 0.351 & 0.000 & 0.314 & 0.000 & -0.749 \\
\hline Quality of sex life & $<---$ & Age & -0.002 & 0.393 & -0.006 & 0.044 & -1.242 \\
\hline Quality of sex life & $<---$ & Job tenure & -0.002 & 0.356 & -0.002 & 0.561 & 0.012 \\
\hline Marital satisfaction & $<---$ & Career self-efficacy & 0.000 & 0.998 & 0.114 & 0.136 & 1.162 \\
\hline Marital satisfaction & $<---$ & Work-life balance & 0.085 & 0.387 & 0.017 & 0.890 & -0.444 \\
\hline Marital satisfaction & $<---$ & age & -0.006 & 0.335 & -0.018 & 0.017 & -1.292 \\
\hline Marital satisfaction & $<---$ & Job tenure & 0.004 & 0.498 & 0.007 & 0.366 & 0.285 \\
\hline Marital satisfaction & $<---$ & Quality of sex life & 1.412 & 0.000 & 1.681 & 0.000 & 1.447 \\
\hline
\end{tabular}

Having shown that there is a difference in the model for men and women, we went further to establish the path along which the difference lies using the critical ratio for differences between groups. Results are contained in Table III. It is shown on the table that the difference lies in the path from career self-efficacy to quality of sex life.

\section{Discussion}

This study investigated the predictive roles of career self-efficacy, work-life balance, age and job tenure on the quality of sex life and marital satisfaction among dualcareer couples in a university environment using the structural equation modelling approach. The study also assessed whether the predicted associations differ between men and women.

Our study found that career self-efficacy is a significant predictor of quality of sex life, work-life balance, with an indirect effect on marital satisfaction for dual-career couples. This shows that for both men and women in the dual-career family, high career self-efficacy leads to a high quality of sex life. Bandura, Caprara, Barbaranelli, Gerbino, and Pastorelli (2003) underscores the importance of affective self-regulatory self-efficacy in the diverse sphere of psychosocial functioning. It should be of note that dual-career employee with strong efficacy believes in his/her ability to accomplish set organizational targets will feel less pressure at work and will prosecute given organizational assignments faster than the dualcareer employee with low self-efficacy beliefs. This belief will also help the employee to cope better with sexual matters than an employee with low efficacy beliefs.

Findings also revealed that work-life balance did not predict marital satisfaction directly but indirectly through the quality of sex life. This further underscores the importance of sexual satisfaction in a dyadic relationship. This outcome supports the findings of Perrone and Worthington (2001) who had earlier reported the importance of sexual satisfaction on marital quality in dual-career marriages. For both men and women in this study, sexual satisfaction serves as the strongest predictor of marital satisfaction. Maslow (1970) argued that sex is an important biological need (like food and water) and that failure to satisfy sexual need may prevent the pursuit of other higher needs.

Age and job tenure did not predict the quality of sex life and marital satisfaction for men. Meanwhile, for women, age has a negative effect on marital satisfaction in that as the dual-career couples increase in age, marital satisfaction decreases. Job tenure has no predictive effect on the women careerists as well. This finding agrees with that of Ismail, Azlan, and Yusoff (2015) who had earlier reported similar results. It could be that for some married women as they age in Nigeria, attention and affection shift from the spouse to the children but may not always be so for the men. This is even more aggravated by the fact that these women are also into full-time employment.

This study concluded that career self-efficacy and work-life balance differentially predict the quality of sex life and marital satisfaction for career men and women, and that age and job tenure are not significant predictors of quality of sex life and marital satisfaction for career men and women.

\section{Practical Implications}

This study exhibits the role of self-efficacy and worklife balance in mitigating the effect of job stress on family life particularly sex life and marital satisfaction. Organizations can assist their employees by organizing psycho-educational programmes that build self-efficacy among employees and assist employees on how to balance work with family life. This knowledge will ease the conflict brought about by workload and family expectations.

\section{References}

Abidogun, J. (2007). Western education's impact on Northern Igbo gender roles in Nsukka, Nigeria. Africa Today, 54(1), 29-51.

Agbalajobi, D. T. (2010). Women's participation and the political process in Nigeria: Problems and prospects. African Journal of Political Science and International Relations, 4(2), 075-082. 
Arthur, M. B., \& Parker, P. (2004). Giving voice to the dualcareer couple. British Journal of Guidance \& Counselling, $32(1), 3-23$.

Balogun, O. A. (2010). Proverbial oppression of women in Yoruba African culture: A philosophical overview. Thought and Practice, 2(1), 21-36.

Bandura, A., Caprara, G. V., Barbaranelli, C., Gerbino, M., \& Pastorelli, C. (2003). Role of Affective Self-Regulatory Efficacy in Diverse Spheres of Psychosocial Functioning. Child Development, 74(3), 769-782.

Chen, G., Gully, S. M., \& Eden, D. (2001). Validation of a new general self-efficacy scale. Organizational Research Methods, 4(1), 62-83.

Cornwall, A. (2002). Spending power: love, money, and the reconfiguration of gender relations in Ado $\square$ Odo, Southwestern Nigeria. American Ethnologist, 29(4), 963980

Dex, S., \& Bond, S. (2005). Measuring work-life balance and its covariates. Work, Employment and Society, 19(3), 627637.

Fischlmayr, I. C., \& Puchmüller, K. M. (2016). Married, mom and manager-how can this be combined with an international career? The International Journal of Human Resource Management, 27(7), 744-765.

Haddock, S. A., \& Rattenborg, K. (2003). Benefits and challenges of dual-earning: Perspectives of successful couples. The American Journal of Family Therapy, 31(5), 325-344.

Hair, J. F., Anderson, R. E., Babin, B. J., \& Black, W. C. (2010). Multivariate data analysis: A global perspective (Vol. 7). New Jersey: Pearson Upper Saddle River.

Hall, F. S., \& Hall, D. T. (1978). Dual-careers-how do couples and companies cope with the problems? Organizational Dynamics, 6(4), 57-77.

Higgins, C. A., \& Duxbury, L. E. (1992). Work-family conflict: A comparison of dual-career and traditionalcareer men. Journal of Organizational Behavior, 13, 389411.

Hill, R. (1 949). Families under stress: Adjustment to crisis separation and reunion. New York: Harper \& Row.

Hu, L., \& Bentler, P. M. (1999). Cutoff criteria for fit indexes in covariance structure analysis: Conventional criteria versus new alternatives. Structural Equation Modelling: A Multidisciplinary Journal, 6(1), 1-55.

Ismail, R., Azlan, H., \& Yusoff, F. (2015). Assessing the relationship between quality of life and marital satisfaction among Malaysian married couples. e-Bangi, 2(1).

Jacobs, J. A., \& Gerson, K. (2001). Overworked individuals or overworked families? Explaining trends in work, leisure, and family time. Work and Occupations, 28(1), 40-63.

Kline, R. B. (2015). Principles and Practice of Structural Equation Modeling (4th ed.). New York: Guilford Publications.

Lirio, P. (2017). Global boundary work tactics: managing work and family transitions in a 24-7 global context. Community, Work \& Family, 20(1), 72-91.

Lupo, C., Guidotti, F., Goncalves, C. E., Moreira, L., Doupona T. M., Bellardini, H., . . . Capranica, L. (2015). Motivation towards dual-career of European student-athletes. European Journal of Sport Science, 15(2), 151-160. doi:10.1080/17461391.2014.940557

Maslow, A. H. (1970). Motivation and personality (2nd ed.). New York: Harper \& Row.
McCubbin, M., \& McCubbin, H. (1987). Families coping with illness: The resiliency model of family stress, adjustment and adaptation. In H. McCubbin \& A. Thompson (Eds.), Family assessment inventories for research and practice (2nd ed., pp. 3-32). Madison, WI: University of Wisconsin-Madison.

McCubbin, M., \& McCubbin, H. (1993). Families coping with illness: The resiliency model of family stress, adjustment, and adaptation. In C. Danielson, 6. Hamel-Bissell, \& P Winstead-Fry (Eds.), Families: Health and illness, perspectives on coping (pp. 20-64). St. Louis, MO: Mosby.

McFall, B. H., \& Murray $\square$ Close, M. (2016). Moving out to move up: dual $\square$ career migration and work-family tradeoffs. Economic Inquiry, 54(1), 44-62.

Moore, O., Gurevich, T., Korczyn, A., Anca, M., Shabtai, H., \& Giladi, N. (2002). Quality of sexual life in Parkinson's disease. Parkinsonism \& Related Disorders, 8(4), 243246.

Motte-Baumvol, B., Bonin, O., \& Belton-Chevallier, L. (2015). Who escort children: mom or dad? Exploring gender differences in escorting mobility among parisian dual-earner couples. Transportation, 44, 139-157.

Perrone, K. M., \& Worthington, E. L., Jr. (2001). Factors influencing ratings of marital quality by individuals within dual-career marriages: A conceptual model. Journal of Counseling Psychology, 48(1), 3-9. doi:10.1037/00220167.48.1.3

Rapoport, R., \& Rapoport, R. N. (1969). The dual-career family: A variant pattern and social change. Human Relations, 22(1), 3-30.

Rapoport, R., \& Rapoport, R. N. (1976). Dual-career families re-examined: new integrations of work \& family. M. Robertson: London.

Robinson, D. L. (1997). Family stress theory: Implications for family health. Journal of the American Academy of Nurse Practitioners, 9(1), 17-24.

Schlessinger, L. (2000). Parenthood by Proxy: Don't have them if you won't raise them: Dr. Laura Schlessinger.

Schooreel, T., \& Verbruggen, M. (2016). Use of familyfriendly work arrangements and work-family conflict: Crossover effects in dual-earner couples. Journal of Occupational Health Psychology, 21(1), 119-132. doi:10.1037/a0039669

Schumm, W. R., Paff-Bergen, L. A., Hatch, R. C., Obiorah, F. C., Copeland, J. M., Meens, L. D., \& Bugaighis, M. A. (1986). Concurrent and discriminant validity of the Kansas Marital Satisfaction Scale. Journal of Marriage and the Family, 48, 381-387.

Shambaugh, R. (2017). Are Chore Wars at Home Holding You Back at Work? Harvard Business Review Digital Articles, 2-5.

Ugwu, L. (2009). Dual-career couples: coping with multiple role stress. Gender and Behaviour, 7(1), 2231-2246.

UNDP. (2013). Human Development Report: Nigeria. Retrieved

http://hdr.undp.org/sites/default/files/CountryProfiles/NGA.pdf

Watanabe, M., Shimazu, A., Bakker, A. B., Demerouti, E., Shimada, K., \& Kawakami, N. (2017). The impact of job and family demands on partner's fatigue: A study of Japanese dual-earner parents. PLoS One, 12(2), e0172291. doi:10.1371/journal.pone.0172291 